\title{
Rate-limiting Steps in Folate Metabolism by Lactobacillus casei
}

\author{
By BARRY SHANE AND E. L. ROBERT STOKSTAD \\ Department of Nutritional Sciences, University of California, \\ Berkeley, California 94720, U.S.A.
}

(Received I8 May 1977)

\begin{abstract}
Oxidation of 5-methyltetrahydrofolate to 5,10-methylenetetrahydrofolate was the ratelimiting step in 5-methyltetrahydrofolate metabolism by Lactobacillus casei. The limiting steps in the utilization of suboptimal levels of folate by $L$. casei were related to the ability of folates to function in purine and/or thymidylate biosynthesis. Folates with glutamate chains of up to at least seven residues were substrates for these biosynthetic enzymes, and comparisons of bacterial growth yields with transport rates for these folates indicated that the polyglutamates were more effective substrates in purine and thymidylate synthesis than the corresponding pteroylmonoglutamates. Lactobacillus casei contained low levels of a $\mathrm{B}_{12}$-independent, pteroylpolyglutamate-specific methionine synthetase. Its methylenetetrahydrofolate reductase also functioned more effectively with pteroylpolyglutamate substrates.
\end{abstract}

\section{INTRODUCTION}

The major route for 5-methyltetrahydrofolate (5-methyl- $\left.\mathrm{H}_{4} \mathrm{PteGlu}\right)$ metabolism in Lactobacillus casei is oxidation with the incorporation of the one-carbon moiety of 5-methyl- $\mathrm{H}_{4}$ PteGlu into thymidylate and purine derivatives (Shane \& Stokstad, 1977).

In this study, the growth requirement of $L$. case $i$ for folates in media containing purines or thymine and the effects of products of one-carbon metabolism on 5-methyl- $\mathrm{H}_{4} \mathrm{PteGlu}$ metabolism were investigated to assess rate-limiting steps in folate metabolism.

\section{METHODS}

Nomenclature. The abbreviations used are: PteGlu, pteroylglutamic acid, folic acid; PteGlu ${ }_{n}$, pteroylmono- to pteroyloligo- $\gamma$-L-glutamic acid, $n$ indicating the number of glutamic acid residues; $\mathbf{H}_{4}$ PteGlu ${ }_{n}$, $5,6,7,8$-tetrahydropteroylmono- to 5,6,7,8-tetrahydropteroyloligo- $\gamma$-L-glutamic acid. The symbols $(l)$ and (d) are used to denote the natural and unnatural diastereoisomers of $\mathrm{H}_{4} \mathrm{PteGlu}_{n}$, respectively, due to the asymmetric centre at the C-6 position, and do not indicate optical activity.

Materials. $(l)-5-\left[\mathrm{Me}^{-14} \mathrm{C}\right]$ Methyl- $\mathrm{H}_{4} \mathrm{PteGlu}_{n}$ (specific activity, $\left.47 \mathrm{mCi} \mathrm{mmol}^{-1}\right),(l)$-10-[formyl $\left.{ }^{-14} \mathrm{C}\right]$ formyl$\mathrm{H}_{4}$ PteGlu (sp. act., $\left.47 \mathrm{mCi} \mathrm{mmol}^{-1}\right)$, and $\mathrm{PteGlu}_{n}(n=\mathrm{I}, 3,5$ and 7$)$ were synthesized and purified as described previously (Shane \& Stokstad, 1976). $\left[{ }^{14} \mathrm{C}\right]$ Formate (sp. act., $47 \mathrm{mCi} \mathrm{mmol}^{-1}$ ) was obtained from Schwarz/Mann (Orangeburg, New Jersey, U.S.A.) and unlabelled purines and pyrimidines, nucleosides and amino acids from Sigma.

Organism and growth conditions. Lactobacillus casei (ATCC7469) was cultured as described previously (Tamura et al., 1972).

Metabolism of $(l)-5$-[Me-14 C]methyl-H ${ }_{4}$ PteGlu. Lactobacillus casei, harvested from growth media in late exponential phase, was washed with, and resuspended $\left(0 \cdot 2 \mathrm{mg}\right.$ dry wt $\left.\mathrm{ml}^{-1}\right)$ in $50 \mathrm{mM}-\mathrm{K}_{2} \mathrm{HPO}_{4} / \mathrm{roo} \mathrm{mM-}$ sodium acetate, adjusted to $\mathrm{pH} 6$ with $\mathrm{H}_{3} \mathrm{PO}_{4}$, and containing $\mathrm{I} \%(\mathrm{w} / \mathrm{v})$ glucose and $5 \mathrm{mM}$-mercaptoethanol. The bacteria were preincubated at $37^{\circ} \mathrm{C}$ for $2 \mathrm{~h}$ before addition of $(l)-5$-[Me- $\left.{ }^{14} \mathrm{C}\right]$ methyl- $\mathrm{H}_{4} \mathrm{PteGlu}^{-}(0 \cdot 45 \mu \mathrm{M})$. After a further $15 \mathrm{~min}$, the bacteria were filtered, resuspended in fresh buffer $\left(0.4 \mathrm{mg} \mathrm{dry} \mathrm{wt} \mathrm{ml}^{-1}\right)$ and reincubated at $37^{\circ} \mathrm{C}$ for $2 \mathrm{~h}$. Intracellular labelled metabolites were extracted with boiling buffer and the incorporation of the labelled one-carbon moiety of 5 -methyl- $\mathrm{H}_{4}$ PteGlu into purines, thymidylate and 
formaldehyde was determined by Sephadex G-25 and DEAE-cellulose chromatography, as described previously (Shane \& Stokstad, 1977). Labelled RNA and DNA in the material not extracted by boiling buffer was determined after treatment with RNAase $T_{2}$, as described previously (Shane \& Stokstad, 1977). In some cases, the insoluble material was treated with $2 \%(\mathrm{w} / \mathrm{v}) \mathrm{HClO}_{4}$ for $5 \mathrm{~min}$ at $4{ }^{\circ} \mathrm{C}$ to extract oligonucleotides, with $10 \% \mathrm{HClO}_{4}$ for $8 \mathrm{~h}$ at $20^{\circ} \mathrm{C}$ to extract $\mathrm{RNA}$, and with $10 \% \mathrm{HClO}_{4}$ for $2 \mathrm{~h}$ at $65{ }^{\circ} \mathrm{C}$ to extract DNA (Feinendegen, Bond \& Painter, 196I).

Enzyme assays. An enzyme extract was prepared by sonicating L. casei $(2 \cdot 7 \mathrm{~g}$ dry wt) in 0.I M-potassium phosphate buffer $\mathrm{pH} 7(20 \mathrm{ml})$ as described by Ohara \& Silber (1969). The sonicated extract was centrifuged (10000 $\mathrm{g}, 15 \mathrm{~min}$ ) and the supernatant was dialysed against two changes of $0 . \mathrm{I} \mathrm{M}$-potassium phosphate buffer $\mathrm{pH} 7$ (1000 vol.).

$\mathrm{B}_{12}$-dependent methionine synthetase [5-methyltetrahydropteroyl-L-glutamate:L-homocysteine $S$-methyltransferase; EC 2.I.I.13] and $\mathbf{B}_{12}$-independent methionine synthetase [5-methyltetrahydropteroyl-tri-Lglutamate:L-homocysteine $S$-methyltransferase; EC 2.I.I.I4] were assayed by slightly modified published procedures (Burton \& Metzenberg, 1975; Cheng, Shane \& Stokstad, 1975; Coward et al., 1975; Kamely, Littlefield \& Erbe, 1973; Taylor \& Weissbach, 1967) as described in Table I. L-Homocysteine was prepared from L-homocysteine thiolactone (Duerre \& Miller, 1966) just before use. $\mathrm{FADH}_{2}$ was prepared by reduction of FAD with $\mathrm{H}_{2} / \mathrm{PtO}_{2}$ (Loughlin, Elford \& Buchanan, 1964).

5,10-Methylenetetrahydrofolate reductase [5-methyltetrahydrofolate: $\mathrm{NAD}^{+}$oxidoreductase; EC I . I . I . 68] was assayed in the reverse direction using menadione as an artificial electron acceptor (Cheng et al., 1975; Katzen \& Buchanan, 1965; Kutzbach \& Stokstad, 197I). The 5, I0-[methylene $\left.{ }^{14} \mathrm{C}\right]$ methylenetetrahydrofolate product formed, when heated at $95^{\circ} \mathrm{C}$ at $\mathrm{pH} 4.5$ in the presence of dimedone, transferred its one-carbon unit to form a formaldehydedimedone adduct which was extracted with toluene. Carrier $\left[{ }^{14} \mathrm{C}\right]$ formaldehyde was added to parallel samples to determine recovery (about $63 \%$ ).

Treatment of kinetic data. $K_{\mathrm{m}}$ and $V_{\max }$ values were determined by an unweighted non-linear regression method (Wilkinson, 1961).

\section{RESULTS}

\section{Methionine synthetase activity}

Although the major route of $5-$ methyl $^{-H_{4}}$ PteGlu metabolism in L. casei does not proceed

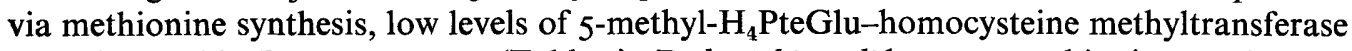
were detected in L. casei extracts (Table I). Escherichia coli has two methionine synthetases (Taylor \& Weissbach, I973; Whitfield, Steers \& Weissbach, 1970). One, a $\mathrm{B}_{12}$-dependent enzyme, will utilize mono- and polyglutamyl methyltetrahydrofolates as substrates, and requires a reducing system and catalytic amounts of $S$-adenosylmethionine (AdoMet) for activity. The other enzyme is $B_{12}$-independent, has no AdoMet or reducing system requirement, but requires phosphate and polyglutamyl methyltetrahydrofolates and is stimulated by $\mathrm{Mg}^{2+}$. The $\mathrm{B}_{12}$-independent enzyme in $L$. casei extracts was measured by assay system $C$ (Table 1 ) whereas assay systems $A$ and $B$ also measured the $B_{12}$-dependent enzyme. In system $A$, the reducing component was $\mathrm{FADH}_{2}$ plus $\mathrm{H}_{2}$ and in $\mathrm{B}$, mercaptoethanol plus cyano-vitamin $B_{12}$ (Taylor \& Weissbach, 1967). Assay $B$, an aerobic assay for the $B_{12^{-}}$ dependent enzyme, is often used for convenience although it is considerably less active than the anaerobic assay $A$.

Activities with each methyltetrahydrofolate substrate were similar in all assay systems (Table I) and no AdoMet requirement was demonstrated. Activity was dependent on the presence of enzyme preparation and homocysteine, and the pentaglutamate substrate was more active than the monoglutamate. These results are consistent with the presence of a $B_{12}$-independent, polyglutamate-specific methyltransferase. Kinetic constants for the methyltetrahydrofolate substrates are shown in Table 2. Although these were evaluated with crude enzyme preparations, the absence of folyl- $\gamma$-glutamyl carboxypeptidase activity in $L$. casei does allow a comparison of folate substrates to be made. At sufficiently low substrate concentrations, the pentaglutamate substrate would be 540 times more effective in methionine synthesis than the monoglutamate. 


\section{Table I. Requirements for methyl group transfer from methyltetrahydrofolates to homocysteine}

The complete reaction mixtures for assay A contained (in $0.3 \mathrm{ml}):(l)-5-\left[\mathrm{Me}^{14} \mathrm{C}\right] \mathrm{methyl}-\mathrm{H}_{4} \mathrm{PteGlu}$ (75 $\mu_{\mathrm{M}}$; sp. act., $47 \mathrm{mCi} \mathrm{mmol}^{-1}$ ) or $(l)-5-\left[\mathrm{Me}_{-1}{ }^{14} \mathrm{C}\right]$ methyl-H ${ }_{4}$ PteGlu $_{5}$ (I $50 \mu_{\mathrm{M}}$; sp. act., $47 \mathrm{mCi}$ $\left.\mathrm{mmol}^{-1}\right)$, L-homocysteine $(500 \mu \mathrm{M}), S$-adenosylmethionine $\left(250 \mu \mathrm{M}\right.$; AdoMet), cyano-vitamin $\mathrm{B}_{12}$ $(50 \mu \mathrm{M})$, mercaptoethanol $(33 \mathrm{mM}), \mathrm{FADH}_{2}(250 \mu \mathrm{M})$, potassium phosphate buffer $\mathrm{pH} 7$ (IO0 mM) and enzyme extract ( $1.54 \mathrm{mg}$ protein, prepared as described in the Methods). The mixtures were incubated under $\mathrm{H}_{2}$ at $37^{\circ} \mathrm{C}$ for $60 \mathrm{~min}$ and the reactions were terminated by adding ice-cold water $(\mathrm{I} \mathrm{ml}) .\left[{ }^{14} \mathrm{C}\right]$ Methionine was separated from labelled folate by chromatography on AG I-X8 columns $(3 \times 0.7 \mathrm{~cm}$; Bio-Rad). The columns were washed with water $(6.7 \mathrm{ml})$ and portions (I $\mathrm{ml})$ of the total effluents $(8 \mathrm{ml})$ were counted.

The complete reaction mixtures for assay B were as in assay A, except that $\mathrm{FADH}_{2}$ was replaced by mercaptoethanol $(200 \mathrm{~mm})$ and the mixtures were incubated aerobically.

The complete reaction mixtures for assay $\mathbf{C}$ were as in assay $\mathbf{B}$ except that AdoMet and vitamin $\mathrm{B}_{12}$ were replaced by $\mathrm{MgCl}_{2}(100 \mu \mathrm{M})$. Mixtures were incubated aerobically.

Blank values were obtained by incubating labelled folates in 0.1 M-potassium phosphate buffer $\mathrm{pH} 7$ under the conditions described for each assay.

$\left.{ }^{[14} \mathrm{C}\right]$ Methionine formed $\left[\mathrm{nmol} \mathrm{h}{ }^{-1}(\mathrm{mg} \text { protein })^{-1}\right]$ from:

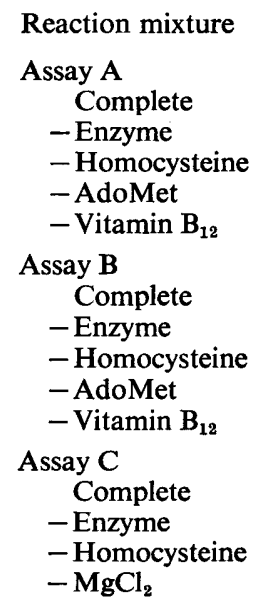

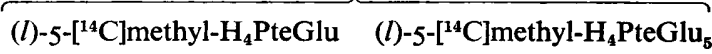

$\begin{array}{ll}0.23 & 0.56 \\ 0.01 & 0.01 \\ 0.08^{*} & 0.02 \\ 0.17 & 0.57 \\ 0.24 & 0.60 \\ & \\ 0.12 & 0.75 \\ 0 & 0 \\ 0.03 & 0.04 \\ 0.11 & 0.79 \\ 0.11 & 0.76 \\ & \\ 0.11 & 0.76 \\ 0 & 0 \\ 0.02 & 0.03 \\ 0.10 & 0.82\end{array}$

* The small amount of activity in the absence of homocysteine probably represents $\left[{ }^{14} \mathrm{C}\right]$ thiomethylmercaptoethanol.

\section{5,10-Methylenetetrahydrofolate reductase activity}

Reductase activity was measured in the reverse direction using menadione as an artificial electron acceptor. Kinetic constants for various $(l)-5-\left[\mathrm{Me}^{-14} \mathrm{C}\right]$ methyltetrahydrofolate substrates are shown in Table 2 . The $K_{\mathrm{m}}$ values decreased with increasing glutamate chain length. No inhibition by AdoMet (I mM) or $S$-adenosylethionine (I mM) was observed. When the reaction was carried out for $12 \mathrm{~h}$ under a $\mathrm{H}_{2}$ atmosphere in the absence of menadione, with larger amounts of extract ( $2 \mathrm{mg}$ protein) and with the various folate substrates, practically no 5,10-methylene- $\mathrm{H}_{4} \mathrm{PteGlu}_{n}$ was detected suggesting that the equilibrium of the reaction favoured methyltetrahydrofolate synthesis.

\section{Effect of unlabelled analogues on $(l)-5-\left[\mathrm{Me}^{-14} \mathrm{C}\right]$ methyl- $\mathrm{H}_{4}$ PteGlu metabolism}

To assess which steps in the metabolism of $5-$ methyl- $\mathrm{H}_{4} \mathrm{PteGlu}$ might be rate-limiting, its metabolism was studied in the presence of a variety of unlabelled analogues. Addition of unlabelled thymidine to the incubation medium decreased the labelled one-carbon incorporation into thymidylate derivatives and DNA but had little effect on labelled onecarbon incorporation into purines (Table 3). Unlabelled adenosine reduced the level of 


\section{Table 2. Kinetic constants of folates for methionine synthetase and} 5, I0-methylenetetrahydrofolate reductase

Methionine synthetase activity was measured using assay $\mathrm{C}$ (see Table $\mathrm{I}$ ) with a 10 min incubation period. 5,10-Methylenetetrahydrofolate reductase activity was assayed as described in Methods. Values for $K_{\mathrm{m}}$ [in $\mu \mathrm{M}$ ] and $V_{\max }$ [in $\mathrm{nmol} \mathrm{h}^{-1}$ (mg protein) $^{-1}$ ] are given as average values \pm maximum deviations, with the number of determinations in parentheses.

Folate

(l)-5-methyl- $\mathrm{H}_{4}$ PteGlu

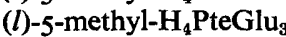
(l)-5-methyl- $\mathrm{H}_{4} \mathrm{PteGlu}_{5}$ (l)-5-methyl- $\mathrm{H}_{4}$ PteGlu
Methionine synthetase

\begin{tabular}{|c|c|}
\hline$K_{\mathrm{m}}$ & $V_{\max }$ \\
\hline $\begin{array}{c}4 I \pm I 7 \\
\text { ND }\end{array}$ & $\begin{array}{c}0.21 \pm 0.03(7) \\
\text { ND }\end{array}$ \\
\hline $0.34 \pm 0.21(7)$ & $0.94 \pm 0.07(7)$ \\
\hline ND & ND \\
\hline
\end{tabular}

5, 10-methylenetetrahydrofolate reductase

$\begin{array}{cc}K_{\mathrm{m}} & V_{\max } \\ 9.5 \pm 2.5(\mathrm{IO}) & 6.0 \pm 0.5(\mathrm{IO}) \\ 4.8 \pm \mathrm{I} \cdot 6 \text { (10) } & 5.4 \pm 0.9(\mathrm{IO}) \\ \mathrm{I} \cdot 8 \pm 0.4 \text { (I0) } & 5.1 \pm 0.2(\mathrm{ro}) \\ \mathrm{I} \cdot \mathrm{I} \pm 0.3(8) & 4.9 \pm 0.4(8)\end{array}$

Table 3. Distribution of labelled metabolites in Lactobacillus casei after incubation with (l)-5-[Me- $\left.{ }^{14} \mathrm{C}\right]$ methyl- $\mathrm{H}_{4}$ PteGlu and unlabelled analogues

Experimental conditions were as described in Methods. Bacteria were preincubated in buffer for $2 \mathrm{~h}$, and with $(\mathrm{l})-5-\left[\mathrm{Me}^{14} \mathrm{C}\right]$ methyl- $_{4} \mathrm{PteGlu}$ for $15 \mathrm{~min}$, and then resuspended in fresh buffer and incubated for $2 \mathrm{~h}$. The preincubation and incubation buffers contained the indicated unlabelled additions (I mM). Results are expressed as pmol ${ }^{14} \mathrm{C}$-label incorporated (mg dry wt bacteria) ${ }^{-1}$.

Additions to medium

Metabolite

Intracellular fraction

Thymidylate*

Purines

Formaldehyde

5-Methyl- $\mathrm{H}_{4}$ PteGlu

Extracellular fraction

Thymidylate*

Purines

Formaldehyde

5-Methyl-H ${ }_{4}$ PteGlu

RNA fraction

Purines

DNA fraction

Thymidylate*

Total
Adenosine

$$
+
$$

None Adenosine Thymidine Thymidine Formate Serine Methionine

$42 \quad 38$

$65 \quad 30$

43

$32 \quad 22$

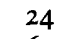

64

2

27

I I

142

9 I

4
149
76
42

\section{4}

154

I 2 I

34

8
127
168

I68

28

$\begin{array}{rrr}22 & 41 & 39 \\ 31 & 65 & 68 \\ 3 & 2 & 2 \\ 7 & 46 & 64\end{array}$

40

19

7

I 2

$\begin{array}{rr}13 & \text { II } \\ 121 & \text { IIO } \\ 53 & 52 \\ 61 & 81\end{array}$

5

$$
14
$$

$$
4
$$

3

387

5
414

24

22

17

472

* Thymidylate derivatives.

labelled purines and RNA in the bacteria but increased the labelled purines in the medium. As the total synthesis of labelled purines was not significantly affected by adenosine, its major effect was probably to inhibit the re-uptake of labelled purines released by the bacteria. Labelled ro-formyl- $\mathrm{H}_{4} \mathrm{PteGlu}$ was not detected. Thymidine and adenosine also increased the level of labelled formaldehyde in the medium at the expense of $5-\left[\mathrm{Me}^{-14} \mathrm{C}\right]-$ methyl- $\mathrm{H}_{4}$ PteGlu. Serine, methionine and uridine (not shown) had no significant effect on the distribution of labelled metabolites. Addition of formate decreased labelled one-carbon incorporation into purines and thymidylate derivatives. Labelled $10-$ formyl- $\mathrm{H}_{4} \mathrm{PteGlu}$ was not detected. A large increase in labelled formaldehyde in the medium was observed and

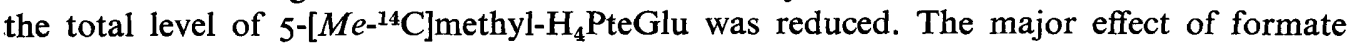
was either to increase the pool of $5,10-$ methylene- $\mathrm{H}_{4} \mathrm{PteGlu}$ with a consequent dilution of the radioactive label or to disturb the equilibrium between $5,10-$ methylene- $\mathrm{H}_{4}$ PteGlu and 


\section{Table 4. Distribution of labelled metabolites in Lactobacillus casei after incubation with labelled formate or folates}

Experimental conditions are described in Methods. Bacteria were preincubated for $15 \mathrm{~min}$ in buffer containing the indicated additions and then resuspended in fresh buffer and incubated for I h.

${ }^{14} \mathrm{C}$-label incorporated [pmol (mg dry wt bacteria) ${ }^{-1}$ ] into:

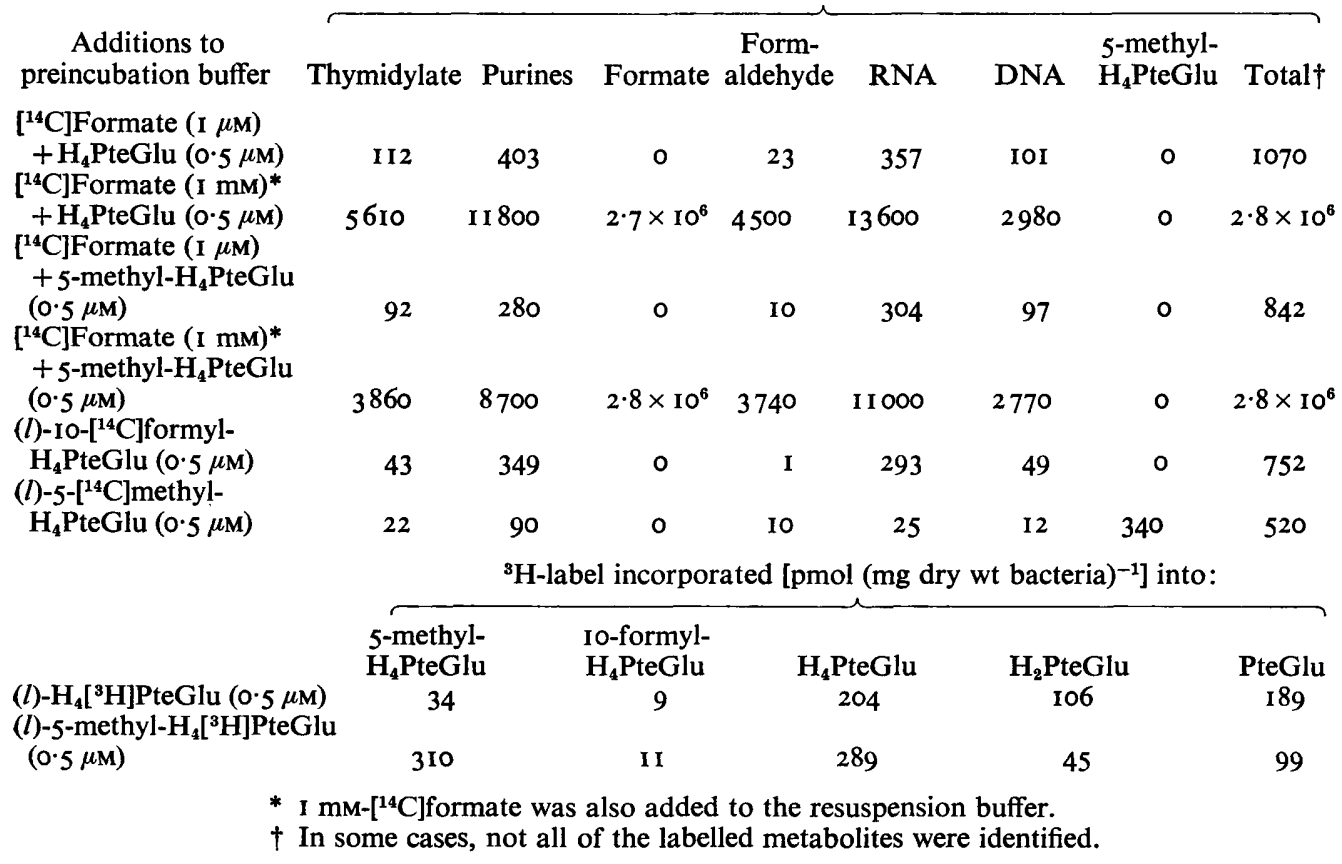

formaldehyde by removing free $\mathrm{H}_{4} \mathrm{PteGlu}$. To investigate whether formate was metabolized to 5 , I0-methylene- $\mathrm{H}_{4} \mathrm{PteGlu}, L$. casei was preincubated with $\left[{ }^{14} \mathrm{C}\right]$ formate and its labelled metabolites were identified.

\section{Metabolism of labelled formate and (l)-10-formyl- $\mathrm{H}_{4}$ PteGlu}

The labelled one-carbon of $\left[{ }^{14} \mathrm{C}\right]$ formate was rapidly incorporated into RNA and DNA (Table 4). The formation of labelled formaldehyde and thymidylate and purine derivatives demonstrated that formate metabolism proceeded via IO-formyl- $\mathrm{H}_{4} \mathrm{PteGlu}$ and 5, IOmethylene- $\mathrm{H}_{4}$ PteGlu. However, no labelled $\mathrm{I}$-formyl- $\mathrm{H}_{4} \mathrm{PteGlu}$ or 5 -methyl- $\mathrm{H}_{4} \mathrm{PteGlu}$ was detected, even when $L$. casei was incubated with I mM- $\left[{ }^{14} \mathrm{C}\right]$ formate. Under these conditions there was an increased incorporation of radioactive label into RNA, DNA, thymidylate, purines and formaldehyde suggesting that the rate-limiting step in formate metabolism was the synthesis of 10 -formyl- $\mathrm{H}_{4} \mathrm{PteGlu}$. Identical labelled metabolites were found after incubating $L$. case $i$ with $(l)$-10-[ formyl- $\left.{ }^{14} \mathrm{C}\right]$ formyl- $\mathrm{H}_{4} \mathrm{PteGlu}$ (Table 4$)$. Within I $\mathrm{h}$, the labelled one-carbon had been incorporated entirely into RNA, DNA, thymidylate and purine derivatives and no labelled folates were detected.

Similar labelled metabolites were found after incubating $L$. casei with $(l)-5-\left[M e-{ }^{14} \mathrm{C}\right]-$ methyl- $\mathrm{H}_{4}$ PteGlu (Table 4). However, the incorporation of the labelled one-carbon into thymidylate and purines proceeded at a much slower rate than was observed with formate and Io-formyl- $\mathrm{H}_{4}$ PteGlu and, after the $\mathrm{I} h$ incubation, much of the 5 -methyl- $\mathrm{H}_{4}$ PteGlu remained unmetabolized. The rate-limiting step in the metabolism of 5 -methyl- $\mathrm{H}_{4} \mathrm{PteGlu}$ was oxidation to 5 , 10 -methylene- $\mathrm{H}_{4}$ PteGlu.

This pattern of metabolism was reflected by the labelled folates found after incubating 
Table 5. Relative yields of Lactobacillus casei in reponse to folates, purines and thymine

Bacterial growth in the presence of the indicated compounds was measured as described by Tamura et al. (1972). Growth responses were assessed using suboptimal concentrations of the compounds (i.e. where cell yield was proportional to the extracellular compound concentration) and is expressed relative to PteGlu (= I00).

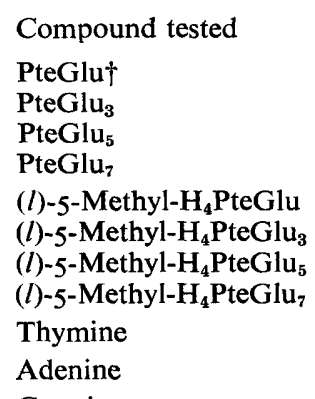

Relative cell yield per nmol in medium* containing:

$\begin{array}{ccc}\text { Purines } & \text { Thymine } & \text { No addition } \\ 100 & 100 & 100 \\ 91 & 107 & 93 \\ 20 & 25 & 26 \\ 2.2 & 2 \cdot 2 & 1.8 \\ \text { II } 5 & 106 & 100 \\ 91 & 93 & 89 \\ 24 & 25 & 23 \\ 0.15 & 0.23 & 0.28 \\ 0.004 & & \\ & 0.0008 & \\ & 0.0007 & \end{array}$

* The medium was a complex mixture (Tamura et al., 1972) containing amongst other compounds: serine ( $3 \mathrm{mM})$, glutamate $(9 \mathrm{mM})$, glycine $(\mathrm{I} \cdot 3 \mathrm{mM})$, methionine $(\mathrm{I} \cdot \mathrm{I} \mathrm{mM})$ and uracil $(45 \mu \mathrm{M})$. Purines (I36 $\mu \mathrm{M})$ [adenine, $37 \mu \mathrm{M}$; guanine, $33 \mu \mathrm{M}$; xanthine, $66 \mu \mathrm{M}$ ] and thymine $(90 \mu \mathrm{M})$ were added to make media containing purines and thymine respectively.

$\dagger$ The cell yield per nmol obtained with suboptimal levels of PteGlu in the medium corresponded to: $E_{640}^{1 \mathrm{~cm}}=296$ for medium containing purines; $E_{640}^{1 \mathrm{~cm}}=\mathrm{I} 24$ for medium containing thymine; and $E_{640}^{1 \mathrm{~cm}}=\mathrm{I} 33$ for medium without additions.

L. casei with $(l)-\mathrm{H}_{4}\left[{ }^{3} \mathrm{H}\right] \mathrm{PteGlu}$ and $(l)-5$-methyl $-\mathrm{H}_{4}\left[{ }^{3} \mathrm{H}\right] \mathrm{PteGlu}$ (Table 4$)$. After the $\mathrm{I} \mathrm{h}$ incubation, $\mathrm{H}_{4}$ PteGlu remained unchanged or had been metabolized mainly to $\mathrm{H}_{2}$ PteGlu or PteGlu. Very little 5-methyl- $\mathrm{H}_{4} \mathrm{PteGlu}$ or $\mathrm{Io}$-formyl- $\mathrm{H}_{4} \mathrm{PteGlu}$ was formed. The patterns of labelling of the folate metabolites derived from 5 -methyl- $\mathrm{H}_{4} \mathrm{PteGlu}$ were similar apart

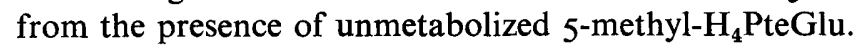

\section{Lactobacillus casei growth response to folates, purines and thymine}

Previous studies have shown that purines and thymine will partially replace the folate requirement of $L$. casei (Rogers \& Shive, 1948; Stokstad, 194I). We confirmed these observations and found that adenine (I mM) plus thymine (IO $\mu \mathrm{M}$ ) was about $80 \%$ as effective as excess folate in promoting growth of this micro-organism. Additional thymine had no effect while additional purine was not investigated due to problems with solubility. Halfmaximum cell yield was achieved with $\mathrm{I} \cdot 8 \mu \mathrm{M}$-thymine (purine in excess) and with $46 \mu \mathrm{M}$ adenine (thymine in excess). Adenosine did not replace adenine as a growth promoter. Uracil was essential for growth in the presence of folates.

As $L$. case $i$ does not possess any $\gamma$-glutamylcarboxypeptidase activity (Buehring, Tamura \& Stokstad, 1974; Shane \& Stokstad, 1975), a comparison of bacterial growth on various pteroylpolyglutamates with either purine or thymine limiting should indicate whether the enzymes responsible for the synthesis of these compounds respond to the same polyglutamate chain lengths. The relative response of $L$. casei to a variety of folates remained the same, regardless of whether purine, thymine, or both were limiting (Table 5). Furthermore, folates with glutamate chain lengths of at least up to seven served as cofactors in purine and thymidylate biosynthesis. Comparisons of the transport rates of these folates with the ability of the folates to promote growth of $L$. casei (Shane \& Stokstad, r976) have shown that the longer chain length polyglutamates are more effectively utilized by the

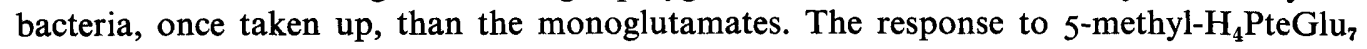


was very poor and, at high concentrations of this compound, the maximum cell yield observed was considerably lower than those obtained with all the other folates tested. The poor cell yield with this compound was almost certainly due to its poor transport into the cell, and was not a result of metabolism, as $\mathrm{PteGlu}_{7}$ was effective in intracellular metabolism. We have previously shown that $5-$ methyl $^{-H_{4}} \mathrm{PteGlu}_{5}$ is poorly transported by $L$. case $i$

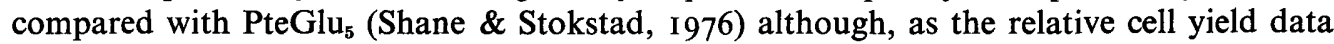
(Table 5) indicate, it is as active as a growth promoter, since it is more effective than PteGlu in intracellular metabolism.

The growth response to folates in the medium with no additions and in the medium containing excess thymine were almost identical (Table 5) indicating that purine biosynthesis was rate-limiting in both cases. The growth response to folates was $2 \cdot 3$-fold higher in medium containing purines, also indicating that less folate was required to meet the organism's thymidylate requirements than its purine requirements. The differences in folate requirement for thymidylate and purine biosynthesis were probably greater than these results suggest, as the purine $(\mathrm{I} 36 \mu \mathrm{M})$ in the medium containing purine was not in excess and some folate was probably utilized for purine biosynthesis. This medium is the standard medium used for the assay of folates in biological samples (Tamura et al., 1972) and contains sufficient purine to prevent spurious results caused by contaminating purines in these samples.

\section{DISCUSSION}

Although other workers could not detect any methionine synthetase activity in $L$. casei (Galivan, 197I ; Kisliuk, I97I), low levels of the enzyme were detected using labelled substrates of high specific activity. The properties of the synthetase were similar to those reported for the polyglutamate-specific, $\mathrm{B}_{12}$-independent enzyme from $E$. coli (Taylor \& Weissbach, I973; Whitfield et al., 1970). (l)-5-Methyl- ${ }_{4} \mathrm{PteGlu}_{5}$ was more than 500 times as effective a substrate as $(l)-5$-methyl- $\mathrm{H}_{4} \mathrm{PteGlu}$ at low substrate levels. No $\mathrm{B}_{12}$-dependent transmethylase was detected although the apoenzyme may have been present, as vitamin $\mathrm{B}_{12}$ was not added to the culture medium. The specific activity of the transmethylase was 2 to 5 orders of magnitude lower than that of thymidylate synthetase (Crusberg, Leary \& Kisliuk, 1970), dihydrofolate reductase, I0-formyltetrahydrofolate synthetase, and 5,10methylenetetrahydrofolate dehydrogenase (Ohara \& Silber, I969; Silber \& Mansouri, I97I) in extracts of $L$. casei.

The 5, ro-methylenetetrahydrofolate reductase of $L$. casei also functioned more effectively with polyglutamyl folate substrates. It was not inhibited by AdoMet which is a noncompetitive inhibitor of the mammalian reductase (Kutzbach \& Stokstad, 1967). However, the equilibrium of the reaction, which favours 5-methyl- $\mathrm{H}_{4} \mathrm{PteGlu}_{n}$ formation, was similar to that observed with the mammalian and Escherichia coli reductases (Cheng et al.,1975; Katzen \& Buchanan, I965; Kutzbach \& Stokstad, 197I). Because of this equilibrium, the reductase reaction has often been considered to be essentially irreversible. The reaction is normally assayed in the reverse direction using menadione as an artificial electron acceptor to drive the oxidation of $5-$ methyl- $_{4} \mathrm{PteGlu}_{n}$ to near completion. However, menadione does not affect the reaction rate for the oxidation of $5-$ methyl- $_{4} \mathrm{PteGlu}_{n}$, it only prevents the 5,Io-methylene- $\mathrm{H}_{4} \mathrm{PteGlu}_{n}$ formed from being reduced back to 5 -methyl- $\mathrm{H}_{4} \mathrm{PteGlu}_{n}$. The kinetic constants obtained for the $L$. casei reductase adequately accounted for the observed metabolism of $5-\left[\mathrm{Me}^{14} \mathrm{C}\right]$ methyl- $\mathrm{H}_{4} \mathrm{PteGlu}$ by this organism and the consequent incorporation of the labelled one-carbon moiety into purine and thymidylate derivatives (Shane \& Stokstad, 1977). The $L$. casei auxotrophic requirement for purines and thymine has been known for some time (Rogers \& Shive, 1948; Stokstad, 194I). However, previously it had been assumed that 5 -methyl- $\mathrm{H}_{4} \mathrm{PteGlu}$ was metabolized via methionine synthesis with the consequent release of $\mathrm{H}_{4}$ PteGlu which could then be utilized for biosynthesis of these compounds. 
Although the equilibrium of the 5,10-methylenetetrahydrofolate reductase reaction appeared to favour the reduction of 5, I0-methylene- $\mathrm{H}_{4} \mathrm{PteGlu}$, the labelled one-carbon of $\left[{ }^{14} \mathrm{C}\right]$ formate was rapidly incorporated into purines and thymidylate via ro-formyl- and 5, 10 -methylene- $\mathrm{H}_{4} \mathrm{PteGlu}$, and not into 5-methyl- $\mathrm{H}_{4}$ PteGlu. Some reduction of $5,10-$ methylene- $\mathrm{H}_{4} \mathrm{PteGlu}$ did occur as evidenced by the metabolism of a small proportion of $\mathrm{H}_{4}\left[{ }^{3} \mathrm{H}\right] \mathrm{PteGlu}$ to 5 -methyl- $\mathrm{H}_{4}\left[{ }^{3} \mathrm{H}\right] \mathrm{PteGlu}$ and the increased net metabolism of $5-\left[\mathrm{Me}^{-14} \mathrm{C}\right]-$ methyl- $\mathrm{H}_{4} \mathrm{PteGlu}$ when the $5,10-$ methylene- $\mathrm{H}_{4} \mathrm{PteGlu}$ pool was expanded after incubating L. case $i$ with I mM-formate. However, the rapid incorporation of the one-carbon moiety of 5, IO-methylene- $\mathrm{H}_{4}$ PteGlu into thymidylate and purines, which is consistent with the relative high levels of thymidylate synthetase and 5,10-methylenetetrahydrofolate dehydrogenase in this bacterium, prevented its reduction back to $5-$ methyl- $_{4} \mathrm{PteGlu}$. Oxidation of 5 -methyl- $\mathrm{H}_{4}$ PteGlu by $5,10-$ methylenetetrahydrofolate reductase was the rate-limiting step in the metabolism of 5 -methyl- $\mathrm{H}_{4}$ PteGlu.

Io-[formyl- $\left.{ }^{14} \mathrm{C}\right]$ Formyl- $\mathrm{H}_{4} \mathrm{PteGlu}$ and $\left[{ }^{14} \mathrm{C}\right]$ formate were rapidly metabolized by $L$. casei with incorporation of the labelled one-carbon moiety into thymidylate and purine derivatives. No labelled ro-formyl- $\mathrm{H}_{4}$ PteGlu was detected after incubating bacteria with I mM$\left[{ }^{14} \mathrm{C}\right]$ formate indicating that the 10 -formyltetrahydrofolate synthetase reaction was ratelimiting in formate metabolism. Although it is possible that some $\left[{ }^{14} \mathrm{C}\right]$ formate was metabolized to $\left[{ }^{14} \mathrm{C}\right]$ purines by non-folate-dependent reactions such as ${ }^{14} \mathrm{CO}_{2}$-fixation, we consider such a mechanism unlikely or, at most, to be responsible for only a small proportion of the labelled purine formed. It should be noted that the thymidylate formed from $\left[{ }^{14} \mathrm{C}\right]-$ formate or $5-\left[\mathrm{Me}^{-14} \mathrm{C}\right]$ methyl- $\mathrm{H}_{4} \mathrm{PteGlu}$ was labelled in the 5-methyl group and not in the pyrimidine ring, demonstrating its formation via $5,10-\left[\right.$ methylene $\left.-{ }^{14} \mathrm{C}\right]$ methylene- $\mathrm{H}_{4} \mathrm{PteGlu}$.

In evaluating intracellular effectiveness of mono- and polyglutamyl folates by comparing growth enhancement with transport rates (Shane \& Stokstad, 1976), two factors should be borne in mind. One is that if a polyglutamate is more effective than a monoglutamate as an enzyme substrate, this increased effectiveness will tend to be magnified due to the exponential growth of the bacteria. However, as the monoglutamate can be metabolized by the micro-organism to polyglutamyl forms, this will tend to have the opposite effect, decreasing the differences between the two forms. Fortunately, $L$. case $i$ has no conjugase enzyme and breakdown of polyglutamates to monoglutamates does not complicate the picture further. Obviously, an exact comparison of various folates cannot be achieved by this method, but a relative comparison can be made.

Comparisons of the transport rates for various folates with their abilities to support growth of $L$. casei (Shane \& Stokstad, 1975, 1976) demonstrated that intracellular polyglutamates were more effective in promoting growth than monoglutamates. This was true regardless of whether purine or thymine was limiting in the medium, although less folate was required to meet the organism's thymidylate requirement than was needed for purine biosynthesis. Polyglutamates of chain length at least up to seven served as cofactors in both purine and thymidylate biosynthesis and no selectivity existed between glutamate chain length requirements for purine biosynthesis compared with thymidylate biosynthesis.

The rate-limiting steps in the intracellular utilization of folates by $L$. casei are obviously related to the ability of folates to act as cofactors in purine and thymidylate biosynthesis. At suboptimal folate concentrations, 5-methyl- $\mathrm{H}_{4} \mathrm{PteGlu}_{n}$ was about equally as effective in promoting growth of $L$. casei as $\mathrm{PteGlu}_{n}$ so oxidation of 5 -methyl- $\mathrm{H}_{4}$ PteGlu does not appear to be limiting in the utilization of folates under these conditions. The most likely rate-limiting steps are the purine and thymidylate biosynthetic reactions themselves. The actual flux through these biosynthetic pathways at limiting folate concentrations will depend on the $K_{\mathrm{m}}$ values of the folate derivatives for the biosynthetic enzymes. The greater growth-promoting abilities of intracellular polyglutamates compared with monoglutamates implies that these polyglutamates have a lower $K_{\mathrm{m}}$ value for the purine and 
thymidylate biosynthetic enzymes than the monoglutamates. While this has not been shown by in vitro studies for the purine biosynthetic enzymes, Kisliuk, Gaumont \& Baugh (1974) have demonstrated that $L$. casei thymidylate synthetase functions more effectively with the hexaglutamate substrate than it does with the corresponding monoglutamate. In addition, polyglutamates such as $5-{\text { methyl }-\mathrm{H}_{4}} \mathrm{PteGlu_{5 }}$ can function in methionine synthesis with the consequent formation of $\mathrm{H}_{4} \mathrm{PteGlu}_{n}$, which can then be utilized for purine and thymidylate synthesis.

Conversion of monoglutamates to polyglutamyl forms cannot be considered ratelimiting in the growth of $L$. casei on monoglutamates since monoglutamates will function in purine and thymidylate biosynthesis. In our experiments, methionine (at about I mM) was supplied in the growth medium. However, if methionine is omitted from the growth medium, the pteroylpolyglutamate synthetase reaction would probably become the ratelimiting step in the utilization of monoglutamates.

This research was supported by United States Public Health Service Grant AM-08 I 7 I from the National Institutes of Health. B.S. is indebted to the Wellcome Trust for a travel grant. We would like to thank Joe Watson for his excellent technical assistance.

\section{REFERENCES}

Buehring, K. U., Tamura, T. \& Stokstad, E. L. R. (1974). Folate coenzymes of Lactobacillus casei and Streptococcus faecalis. Journal of Biological Chemistry 249, 1081-1089.

Burton, E. G. \& MetzenberG, R. L. (1975). Regulation of methionine biosynthesis in Neurospora crassa. Archives of Biochemistry and Biophysics 168, 219-229.

Cheng, F. W., Shane, B. \& Stokstad, E. L. R. (1975). Pentaglutamate derivatives of folate as substrates for rat liver tetrahydropteroylglutamate methyltransferase and 5,10-methylenetetrahydrofolate reductase. Canadian Journal of Biochemistry 53, 1020-1027.

Coward, J. K., Chello, P. L., Cashmore, A. R., Parameswaran, K. N., DeAngelis, L. M. \& BerTINO, J. R. (1975). 5-Methyl-5,6,7,8-tetrahydropteroyl oligo- $\gamma$-L-glutamates: synthesis and kinetic studies with methionine synthetase from bovine brain. Biochemistry 14, 1548-1552.

Crusberg, T. C., Leary, R. \& Kisliuk, R. L. (1970). Properties of thymidylate synthetase from dichloromethotrexate-resistant Lactobacillus casei. Journal of Biological Chemistry 245, 5292-5296.

Duerre, J. A. \& Miller, C. H. (I966). Preparation of L-homocysteine from L-homocysteine thiolactone. Analytical Biochemistry 17, 310-31 5.

Feinendegen, L. E., Bond, V. P. \& Painter, R. B. (1961). Studies on the interrelationship of RNA synthesis, DNA synthesis and precursor pool in human tissue culture cells studied with tritiated pyrimidine nucleosides. Experimental Cell Research 22, 381-405.

Galivan, T. (1971). Discussion on folate compounds - chemistry and enzymology. Annals of the New York Academy of Sciences 186, 83.

Kamely, D., Littlefield, J. W. \& ERBe, R. W. (1973). Regulation of 5-methyltetrahydrofolate: homocysteine methyltransferase activity by methionine, vitamin $\mathrm{Br}_{12}$, and folate in cultured I8 baby hamster kidney cells. Proceedings of the National Academy of Sciences of the United States of America 70, 2585-2589.

Katzen, H. M. \& Buchanan, J. M. (1965). Enzymatic synthesis of the methyl group of methionine. Journal of Biological Chemistry 240, 825835 .

KIsLIUK, R. L. (1971). Discussion on folate compounds - chemistry and enzymology. Annals of the New York Academy of Sciences 186, 83 .

Kisliuk, R. L., Gaumont, Y. \& Baugh, C. M. (1974). Polyglutamyl derivatives of folate as substrates and inhibitors of thymidylate synthetase. Journal of Biological Chemistry 249, 41004 IO3.

Kutzbach, C. \& Stoksiad, E. L. R. (1967). Feedback inhibition of methylenetetrahydrofolate reductase in rat liver by $S$-adenosylmethionine. Biochimica et biophysica acta 139, 217-220.

Kutzbach, C. \& Stokstad, E. L. R. (I97I). Mammalian methylenetetrahydrofolate reductase. Biochimica et biophysica acta 250, 459-477.

Loughlin, R. E., Elford, H. L. \& Buchanan, J. M. (1964). Enzymatic synthesis of the methyl group of methionine. VII. Isolation of a cobalamincontaining transmethylase (5-methyltetrahydrofolate-homocysteine) from mammalian liver. Journal of Biological Chemistry 239, 2888-2895.

OharA, O. \& Silber, R. (I969). Studies on the regulation of one-carbon metabolism. The effects of folate concentration in the growth medium on the activity of three folate-dependent enzymes in Lactobacillus casei. Journal of Biological Chemistry 244, 1988-1993.

Rogers, L. L. \& SHIVE, W. (1948). Biochemical transformations as determined by competitive analoguemetabolite growth inhibitions. VII. Relationship of purines and thymine to folic acid. Journal of Biological Chemistry 172, 75I-758.

MIC IO3 
Shane, B. \& Stokstad, E. L. R. (1975). Transport and metabolism of folates by bacteria. Journal of Biological Chemistry 250, 2243-2253.

Shane, B. \& Stokstad, E. L. R. (I976). Transport and utilization of methyltetrahydrofolates by Lactobacillus casei. Journal of Biological Chemistry 25I, 3405-3410.

Shane, B. \& Stokstad, E. L. R. (1977). Metabolism of 5-methyltetrahydrofolate by Lactobacillus casei. Journal of General Microbiology 103, 249-259.

Silber, R. \& MANsouri, A. (I97I). Regulation of folate-dependent enzymes. Annals of the New York Academy of Sciences 186, 55-69.

Stokstad, E. L. R. (194I). Isolation of a nucleotide essential for the growth of Lactobacillus casei. Journal of Biological Chemistry 139, 475-476.

Tamura, T., Shin, Y. S., Williams, M. A. \& StokSTAD, E. L. R. (1972). Lactobacillus casei response to pteroylpolyglutamates. Analytical Biochemistry 49, 5I7-52I.

TAYlOR, R. T. \& WeISSBACH, H. (1967). $N^{5}$-Methyltetrahydrofolate-homocysteine transmethylase. Partial purification and properties. Journal of Biological Chemistry 242, I 502-1 508.

TAYLOR, R. T. \& WeISSBACH, H. (I973). $N^{5}$-Methyltetrahydrofolate-homocysteine methyltransferases. In The Enzymes, 3rd edn, vol. 9, pp. I 2 I-I65. Edited by P. D. Boyer. New York: Academic Press.

Whitfield, C. D., Steers, E. J., JR \& Weissbach, H. (1970). Purification and properties of 5-methyltetrahydropteroyltriglutamate-homocysteine transmethylase. Journal of Biological Chemistry 245, 390-401.

Wilkinson, G. N. (196I). Statistical estimations in enzyme kinetics. Biochemical Journal 80, 324-332. 